日本臨床麻酔学会第 31 回大会パネルディスカッション

日臨麻会誌 Vol.33 No.2, $205 ＼mathrm{~ 211, ~} 2013$

新しい筋弛緩回復薬

日本における筋弛緩拮抗と残存の状況

中塚逸央*

[要旨］筋弛緩モニターなしでロクロニウムを使用した全身麻酔手術後にネオスチグミンまたはス ガマデクスを投与して筋弛緩を拮抗し, 四連反応比く 0.9 となる残存筋弛緩の発生率を調査した. 筋弛緩拮抗後, 筋弛緩からの回復を主観的に確認した後に抜管した直後の残存筋弛緩はネオスチグ ミン群では23.9\%の患者に見られたが, スガマデクスを用いた場合は 4.3\%と有意に少なかった. ネオスチグミン群での残存筋弛緩の要因として, 高齢者, ロクロニウムの追加投与量が多い例, ネ オスチグミンの投与量が少ない例やロクロニウムの最終投与からネオスチグミンの投与までの時間 が短い例を認めたが, スガマデクスでの残存筋弛緩の要因としてはっきりしたものはなかった. キーワード : ロクロニウム, ネオスチグミン, スガマデクス, 残存筋弛緩

\section{はじめに}

全身麻酔手術後の筋弛緩効果の残存により，上気 道閉塞による低酸素血症や咽喉頭機能低下による誤

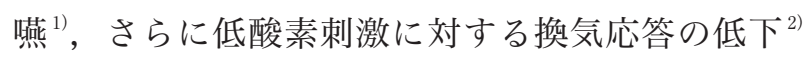
といった問題が引き起こされる．従来のネオスチグ ミンによる筋弛緩拮抗は効果発現までの時間や効果 の確実性に問題があり，また副作用にも注意が必要 であった。 2010 年に発売されたスガマデクスは副 作用も少なく, 用量依存性に速やかにロクロニウム の筋弛緩効果を拮抗できるとされ, 術後残存筋弛緩 の発生頻度を低下させることが期待できる。本稿で は多施設共同研究の結果を踏まえ両拮抗薬使用時 の残存筋弛緩の発生頻度の違いや背景因子を提示 する。

\section{I 対象と方法}

研究は東邦大学, 東京女子医科大学, 日本大学, 慶應義塾大学の各大学附属病院でスガマデクスの発 売前後に行った。それぞれの施設で倫理委員会の承 認を受け, 患者に対して研究方法を説明し, 文書に よる同意を得た。

対象は，全身麻酔時の筋弛緩薬としてロクロニウ ムを投与され，手術を受ける年齢 18 歳以上，ASA physical status $1 \sim 3$ の患者とし, 除外基準は, 口 クロニウム，スガマデクス，ネオスチグミン，アト ロピンに対して過敏症の既往歴のある患者，重症筋 無力症患者または筋無力症症候群の患者とした.

手術患者の状態に適合した麻酔薬と麻酔鎮痛薬を 用いて麻酔導入および麻酔維持を行った。麻酔維持 は吸入麻酔またはプロポフォールを用いた完全静脈 麻酔のいずれでも可とした。ロクロニウムは挿管量
著者連絡先 中塚逸央

帛160-8582 東京都新宿区信濃町 35 慶應義塾大学医学部麻酔学教室 


\section{表 1 患者背景}

\begin{tabular}{ccc}
\hline & スガマデクス群 & ネオスチグミン群 \\
\hline 性別(男性/女性) & $43 / 74$ & $44 / 65$ \\
年齢(歳) & $58.0 \pm 18.4$ & $56.0 \pm 16.4$ \\
身長 $(\mathrm{cm})$ & $159.4 \pm 8.8$ & $160.0 \pm 8.9$ \\
体重 $(\mathrm{kg})$ & $55.2 \pm 11.1$ & $57.8 \pm 11.2$ \\
ASA 分類(PS1/PS2) & $52 / 65$ & $49 / 60$ \\
手術時間(分) & $158.4 \pm 112.2$ & $202.1 \pm 121.6^{*}$ \\
維持麻酔薬 & $80 / 37$ & $73 / 36$ \\
(セボフルランフフプロ & & \\
\hline
\end{tabular}

平均土標準偏差または人数 ${ }^{*}: \mathrm{p}<0.05 \mathrm{vs}$. スガマデクス群

として $0.6 〜 0.9 \mathrm{mg} / \mathrm{kg}$ を投与し，追加量として 0.1 $\sim 0.2 \mathrm{mg} / \mathrm{kg}$ を麻酔担当医が筋弛緩モニターなしで 術中必要に応じて用いた。

スガマデクス発売前の第 1 期には，手術終了後ネ オスチグミンをアトロピンとともに投与し筋弛緩を 拮抗した(ネオスチグミン群)。ネオスチグミンの量 は麻酔担当医の判断で決定したが，ネオスチグミン とアトロピンの投与量の比は $2: 1$ とした。スガマ デクス発売後の第 2 期には, 手術終了後自発呼吸や 体動などが見られた場合はスガマデクス $2 \mathrm{mg} / \mathrm{kg}$ を，見られない場合は $4 \mathrm{mg} / \mathrm{kg}$ 投与して筋弛緩を拮 抗した(スガマデクス群)。ともに呼吸や握力など筋 弛緩からの回復を主観的に確認した後に抜管した。

抜管後安定時に, 筋弛緩モニター(TOFウォッチ $\mathrm{SX}^{\circledR}$ )を用い, 尺骨神経に 50mAの train of four (TOF) 刺激を 15 秒間隔で与えて, 母指における四連反応 比(TOFR : train of four ratio)を 2 回測定した。な お測定はハンドアダプターを装着して行った。 $2 つ$ の值が $10 \%$ 以内であった場合はそれらの平均值を デー夕処理に用い，それ以上であった場合は安定す るまで最大 4 回測定し, 中央值をデー夕処理に用い

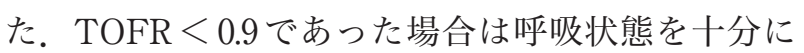
観察するとともに必要に応じて再度同じ薬剤で筋弛 緩を拮抗した。

主評価項目は抜管後の TOFR $<0.9$ の症例数で, 副次評価項目は術後の肺合併症などの有無，ロクロ
ニウムの総投与量，抜管から TOFR 測定までの時 間, 最後のロクロニウム投与から抜管までの時間, リバース剂投与から抜管までの時間，年齢・維持麻 酔法による差とした。

デー夕は平均土標準偏差で表わした。統計処理は 対応のないt検定と $\chi$ 二乗検定で行い, $\mathrm{p}<0.05$ を もって有意差ありとした。

\section{II 結 果}

両群間に性別, 年齢, 身長, 体重, ASA 分類, 維持麻酔薬に有意差はなかった(表 1)。手術時間は スガマデクス群の方が有意に短かった(表 1)。その ためロクロニウムの投与量に両群間に差は見られな かったが，体重と時間当たりのロクロニウムの全投 与量はスガマデクス群で有意に多かった(表2)。ま たロクロニウム最終投与から筋弛緩拮抗, 抜管, TOF 測定までの時間と筋弛緩拮抗から TOF 測定ま での時間はスガマデクス群の方が有意に短かった (表2).

TOFR $<0.9$ の術後残存筋弛緩はネオスチグミン 群(109人)の $23.9 \%(26$ 人) とスガマデクス群 $(117$ 人)の $4.3 \%$ (5人)に見られた $(\mathrm{p}<0.0001)$. 術後に残 存筋弛緩が原因と思われる合併症を認めたものはな かった。

ネオスチグミン群での残存筋弛緩の要因として, 高齢，ASA 分類が高いこと，セボフルラン麻酔があ 
表 2 薬剤の投与状況と測定時間

\begin{tabular}{ccc}
\hline & スガマデクス群 & ネオスチグミン群 \\
\hline ロクロニウム挿管用量 $(\mathrm{mg})$ & $43.4 \pm 10.0$ & $43.3 \pm 9.3$ \\
ロクロニウム追加用量 $(\mathrm{mg})$ & $29.5 \pm 30.4$ & $28.9 \pm 29.6$ \\
ロクロニゥム全投与量 $(\mathrm{mg})$ & $72.9 \pm 33.7$ & $72.2 \pm 32.0$ \\
ロクロニウム全投与量 $(\mathrm{mg} / \mathrm{kg})$ & $1.33 \pm 0.56$ & $1.26 \pm 0.54$ \\
ロクロニゥム全投与量 $(\mathrm{mg} / \mathrm{kg} / \mathrm{hr})$ & $0.68 \pm 0.45$ & $0.45 \pm 0.20^{*}$ \\
リバース剂投与量 & $2.7 \pm 1.0 \mathrm{mg} / \mathrm{kg}$ & $32.9 \pm 8.7 \mu \mathrm{g} / \mathrm{kg}$ \\
最終投与からリバース剂投与まで(分) & $71.5 \pm 42.2$ & $87.3 \pm 51.4^{*}$ \\
リバース剂投与からTOF測定まで(分) & $8.0 \pm 4.0$ & $11.5 \pm 8.3^{*}$ \\
最終投与から抜管まで(分) & $76.9 \pm 42.8$ & $94.4 \pm 51.4^{*}$ \\
最終投与からTOF測定まで(分) & $79.5 \pm 42.7$ & $98.9 \pm 50.6^{*}$ \\
\hline
\end{tabular}

平均土標準偏差または人数 $\quad{ }^{*}: \mathrm{p}<0.05 \mathrm{vs}$. スガマデクス群

表 3 残存筋弛緩の要因(ネオスチグミン群)

\begin{tabular}{|c|c|c|}
\hline & TOFR $<0.9$ & TOFR $\geq 0.9$ \\
\hline 性別 (男性 / 女性) & $13 / 13$ & $31 / 52$ \\
\hline 年齢(歳) & $63.2 \pm 12.9$ & $53.7 \pm 16.8^{*}$ \\
\hline 身長 (cm) & $159.0 \pm 8.6$ & $160.3 \pm 9.0$ \\
\hline 体重 (kg) & $56.5 \pm 8.1$ & $58.2 \pm 12.0$ \\
\hline ASA 分類 (PS1/PS2) & $7 / 19$ & $42 / 41 *$ \\
\hline 手術時間 & $236.6 \pm 135.9$ & $191.4 \pm 115.6$ \\
\hline $\begin{array}{c}\text { 維持麻酔薬 } \\
\text { (セボフルラン/プロポフォール) }\end{array}$ & $22 / 4$ & $51 / 32 *$ \\
\hline ロクロニウム挿管用量 (mg) & $43.8 \pm 8.0$ & $43.2 \pm 9.7$ \\
\hline ロクロニウム追加用量 (mg) & $41.5 \pm 29.9$ & $24.9 \pm 28.6^{*}$ \\
\hline ロクロニウム全投与量 (mg) & $85.4 \pm 31.1$ & $68.1 \pm 31.4^{*}$ \\
\hline ロクロニウム全投与量 (mg/kg) & $1.54 \pm 0.62$ & $1.18 \pm 0.48^{*}$ \\
\hline ロクロニウム全投与量 (mg/kg/hr) & $0.47 \pm 0.19$ & $0.45 \pm 0.20$ \\
\hline ネオスチグミン投与量 $(\mu \mathrm{g} / \mathrm{kg})$ & $29.7 \pm 10.7$ & $33.9 \pm 7.8^{*}$ \\
\hline 最終投与からリバース剂投与まで(分) & $63.2 \pm 22.0$ & $94.9 \pm 55.4^{*}$ \\
\hline リバース剂投与から TOF 測定まで (分) & $11.8 \pm 10.1$ & $11.5 \pm 7.7$ \\
\hline 最終投与から抜管まで(分) & $69.6 \pm 23.0$ & $102.1 \pm 55.4^{*}$ \\
\hline 最終投与から TOF 測定まで (分) & $75.0 \pm 22.8$ & $106.3 \pm 54.5^{*}$ \\
\hline
\end{tabular}

平均土標準偏差または人数 $\quad{ }^{*}: \mathrm{p}<0.05 \mathrm{vs}$. TOFR $<0.9$

つた(表3).また TOFRが 0.9 未満の患者ではTOFR が 0.9 以上の患者と比較して, ロクロニウムの追加 投与量が多く，ネオスチグミンの投与量が少なく， ロクロニウムの最終投与からネオスチグミン投与, 抜管, TOF 測定までの時間が短かった(表 3)(図1). 一方，スガマデクス群での残存筋弛緩の要因として はっきりしたものはなかった(表4)。ただし，
TOFR $<0.9$ が見られた 5 人はすべて術中麻酔はセ ボフルラン麻酔で，ロクロニウム最終投与から TOF 測定までの時間は 100 分以内で，スガマデク ス投与量は $2 \mathrm{mg} / \mathrm{kg}$ 程度であった(表 4) (図 1).

スガマデクス投与後の筋弛緩回復不良の自験例を 示す. ASA分類 2 の 43 歳女性で身長 $167 \mathrm{~cm}$, 体重 $49 \mathrm{~kg}$. 合併症として鉄欠乏性貧血, 既往歴として 


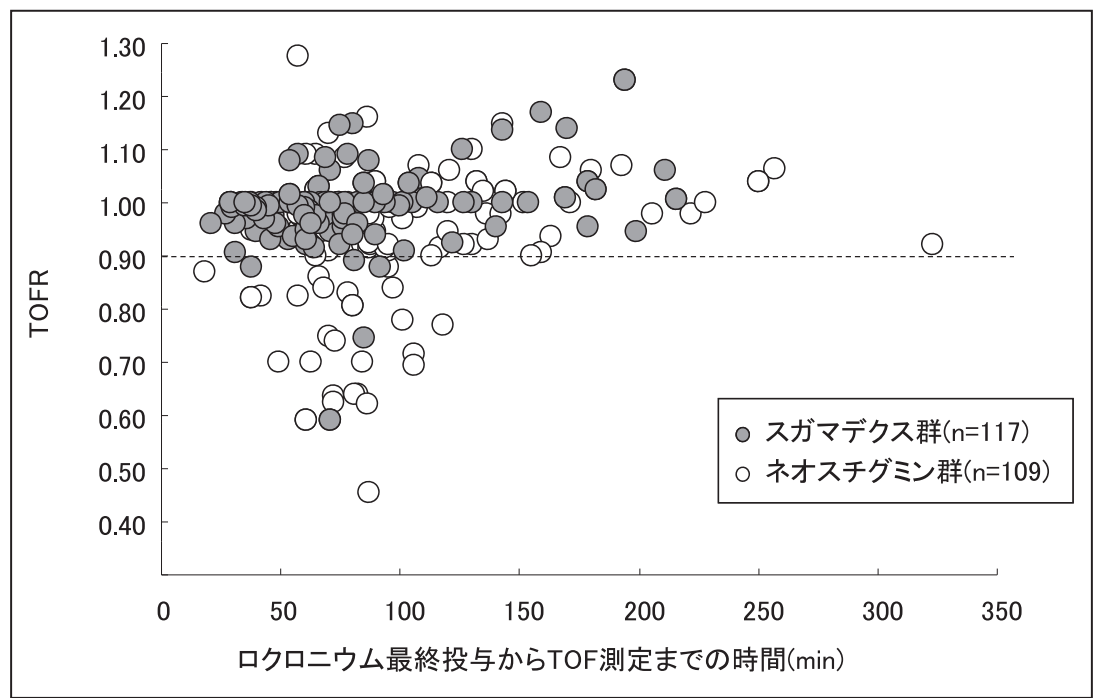

图1 ロクロニウム最終投与から TOF測定までの時間とTOF 比との関連

甲状腺機能元進症があったが，手術時にはホルモン 值は正常であった。腹腔鏡下子宮筋腫核出術をセボ フルラン麻酔で行った(手術時間 107 分)。ロクロニ ウムの挿管量は $30 \mathrm{mg}$ で追加量は $10 \mathrm{mg}$ であった. ロクロニウム最終投与から 64 分後にスガマデクス $100 \mathrm{mg}$ を投与した。全覚醒, 自発呼吸良好，掌握 5 秒を確認して抜管したが，スガマデクス投与 7 分後 の TOFRは 0.59 であった。回復室での 30 分後の観 察では複視なし, $\mathrm{SpO}_{2}$ 低下なし, 舌根沈下なしで あったが，5秒間の頭部挙上は不可であった。

\section{III 考 察}

体重と時間当たりのロクロニウムの投与量はスガ マデクス群の方が多かったにもかかわらず，TOFR が 0.9 未満の術後残存筋弛緩の発生率はスガマデク ス群ではネオスチグミン群の $1 / 5$ 以下であった。

今回残存筋弛緩の判断基準として TOFR $<0.9$ を 用いた。TOFRが 0.9 を下回ると握力の低下や咬筋 の筋力低下が起こり ${ }^{3)}$, またオトガイ舌筋の機能低 下や上気道の断面積も減少する ${ }^{4)}$ た上気道閉塞の リスクが高まる。実際，Murphyらの報告によると 上気道閉塞や，低酸素血症などの critical respiratory eventsはPACU入室後 15 分の間に $0.8 \%$ の患者に見
られたが，年齢・性別・手術をマッチさせた患者と 比較すると，TOFRが 0.9 以上の患者は有意に少な く, TOFRが 0.7 未満の患者は有意に多いという結 果であった ${ }^{1)}$ 。またTOFRが $0.9 に$ 回復していても 複視等の視力障害や全般的な疲労を感じると報告さ れている ${ }^{3)}$.

ロクロニウムを用いた麻酔での抜管時の残存筋弛 緩の発生率はいくつかの研究で示されている(表 5). 報告により発生率は異なるが，Gätke らの報告では 麻酔を TIVA で行い，抜管後の TOFR $<0.8$ の頻度 は筋弛緩モニターなしの麻酔の場合は $16.7 \%$ であっ


た ${ }^{5)}$. Maybauer らによれば筋弛緩モニタリングを していても筋弛緩拮抗をしなければ44\%の患者で 抜管予定時間に TOFRが 0.9 未満となっている ${ }^{6}$. Baillard らは術後残存筋弛緩の要因として，筋弛緩 モニタリングをしていないこと，筋弛緩薬の拮抗を していないことと手術時間をあげている ${ }^{7)}$. 本研究 では術中に筋弛緩モニタリングを行わなかったが, 行った場合の残存筋弛緩の発生率は少なくなった可 能性がある。

さらに抜管は呼吸状態や握力などを見て筋弛緩か らの回復を主観的に判断して行った。さまざまな臨 
表 4 残存筋弛緩の要因 (スガマデクス群)

\begin{tabular}{|c|c|c|}
\hline & TOFR $<0.9$ & TOFR $\geq 0.9$ \\
\hline 性別 (男性 / 女性) & $1 / 4$ & $42 / 70$ \\
\hline 年齢(歳) & $64.4 \pm 21.9$ & $57.7 \pm 18.2$ \\
\hline 身長 (cm) & $156.8 \pm 8.4$ & $159.5 \pm 8.8$ \\
\hline 体重 (kg) & $51.0 \pm 3.1$ & $55.4 \pm 11.3$ \\
\hline ASA 分類 (PS1/PS2) & $2 / 3$ & $50 / 62$ \\
\hline 手術時間 & $199.0 \pm 155.9$ & $156.6 \pm 110.5$ \\
\hline $\begin{array}{c}\text { 維持麻酔薬 } \\
\text { (セボフルランンフプポフォル) }\end{array}$ & $5 / 0$ & $75 / 37$ \\
\hline ロクロニウム挿管用量 (mg) & $36.0 \pm 8.9$ & $43.7 \pm 9.9$ \\
\hline ロクロニウム追加用量 (mg) & $40.0 \pm 41.2$ & $29.1 \pm 30.0$ \\
\hline ロクロニウム全投与量 (mg) & $76.0 \pm 42.8$ & $72.8 \pm 33.5$ \\
\hline ロクロニウム全投与量 (mg/kg) & $1.48 \pm 0.77$ & $1.32 \pm 0.55$ \\
\hline ロクロニウム全投与量 $(\mathrm{mg} / \mathrm{kg} / \mathrm{hr})$ & $0.51 \pm 0.17$ & $0.68 \pm 0.46$ \\
\hline スガマデクス投与量 (mg/kg) & $2.0 \pm 0.1$ & $2.7 \pm 1.0$ \\
\hline $\begin{array}{c}\text { スガマデクス投与量 } \\
(3 \mathrm{mg} / \mathrm{kg} \text { 未満/3mg/kg以上) }\end{array}$ & $5 / 0$ & $75 / 37$ \\
\hline 最終投与からリバース剤投与まで(分) & $66.6 \pm 19.5$ & $71.7 \pm 43.0$ \\
\hline リバース剤投与から TOF測定まで(分) & $6.8 \pm 3.0$ & $8.0 \pm 4.0$ \\
\hline 最終投与から抜管まで(分) & $71.2 \pm 20.8$ & $77.1 \pm 43.6$ \\
\hline 最終投与から TOF 測定まで(分) & $73.4 \pm 21.2$ & $79.8 \pm 43.4$ \\
\hline
\end{tabular}

平均土標準偏差または人数

床的な回復の指標と実際に TOFRが 0.9 未満である こととは乘離が見られる。Cammuらは，5秒間の 頭部挙上・足の挙上・握手等ができる, 舌圧子を保 持できるといった臨床所見を認める患者の中で TOFRが 0.9 以上であるのは約 $64 \%$ であると報告し ており ${ }^{8)}$, 今回の結果からもネオスチグミンで筋弛 緩を拮抗する場合は特に, 臨床所見だけで筋弛緩の 残存を判断するのは難しいといえる.

Murphyらによるとネオスチグミンで拮抗後, 抜 管時の TOFR $<0.9$ の頻度は $88 \%$ で，抜管 8 分後の PACU入室時にはこの頻度は $32 \%$ に有意に低下し ていた. ネオスチグミンの効果が現われるまでに は 5〜10分以上かかることから，抜管時に筋弛緩 が残存していてもリカバリー室等にいる間に徐々に 回復するということが考えられる.今回の研究では ネオスチグミン投与から TOF 測定までの時間は残 存筋弛緩の有無で差がなかった。このことから高齢
者やロクロニウムの投与量が多い症例，吸入麻酔薬 で維持した場合，ロクロニウム最終投与からあまり 時間がたつていない場合などはネオスチグミンによ る筋弛緩拮抗に時間がかかるということを念頭に置 く必要があるといえる。またリカバリ一室等に入室 せずに直接病棟へ帰るような場合には，観察が不十 分となる移動中の上気道閉塞のリスクも考慮しなけ ればならない.

スガマデクスを使用した場合には残存筋弛緩が起 こる要因としてはっきりしたものはなく，おおむね どの患者も十分に筋弛緩を拮抗することができた。 TOFRが 0.9 未満であった 5 人の麻酔はすべてセボ フルラン麻酔であったが，プロポフォール麻酔とセ ボフルラン麻酔でスガマデクスによる筋弛緩回復時 間に有意差はなかったという報告もある ${ }^{10)}$ 。また 5 人ともスガマデクスの投与量は $2 \mathrm{mg} / \mathrm{kg}$ で，体動が 見られたときの投与量としては通常十分と思われる 
表 5 抜管時の残存筋弛緩の発生率

\begin{tabular}{ccccccc}
\hline 発生率 & 拮抗 & モニタリング & TOFR & 麻酔 & 患者数 & 著者 \\
\hline $16.7 \%$ & ネオスチグミン $( \pm)$ & - & $<0.8(\mathrm{MMG})$ & TIVA & 60 & Gätke $^{5)}$ \\
$3.3 \%$ & ネオスチグミン $( \pm)$ & + & $<0.8(\mathrm{MMG})$ & TIVA & 60 & Gätke $^{5)}$ \\
$88 \%$ & ネオスチグミン & + & $<0.9(\mathrm{AMG})$ & セボフルラン & 120 & Murphy $^{9)}$ \\
$44 \%$ & $(-)$ & + & $<0.9(\mathrm{AMG})$ & TIVA & 142 & Maybauer $^{6)}$ \\
$4.3 \%$ & スガマデクス & - & $<0.9(\mathrm{AMG})$ & Both & 117 & 本研究 \\
$23.9 \%$ & ネオスチグミン & - & $<0.9(\mathrm{AMG})$ & Both & 109 & 本研究 \\
\hline
\end{tabular}

MMG : mechanomyography, AMG : acceleromyography

が，投与量が少ない場合 ${ }^{11}$ や高齢者 ${ }^{12)}$ などではスガ マデクスの効果が現われるまでに時間がかかると報 告されており, 場合によっては拮抗時の筋弛緩のレ ベルを筋弛緩モニターで確認する必要があるだろ う.

ロクロニウムを挿管時のみに用いた場合などは筋 弛緩を拮抗せずに抜管する場合もあるかもしれな い. しかし，抻管から 2 時間以上たった後でも $37 \%$ の患者はTOFRが 0.9 未満であったという報告もあ $り^{13)}$ ，単回使用かつ時間がたつているというだけで は筋弛緩から回復しているとはいえない。また Fuchs-Buderらによるとイソフルラン麻酔中, ベ クロニウム投与後 TOFRが平均 0.87 まで回復した ときに $\mathrm{MgSO}_{4}$ を $60 \mathrm{mg} / \mathrm{kg}$ 投与したところ, TOF response 3 になったという ${ }^{14)}$. 今回 TOFRが 0.9 以 上に回復した患者でもシバリングで $\mathrm{MgSO}_{4}$ を投与 されるようなことがあれば recurarizationを起こす 可能性があることを考えると，ロクロニウムのアセ チルコリン受容体占有率をなるべく低くするために も筋弛緩の拮抗は必要である。

以上よりネオスチグミンと比較してスガマデクス では，80\%以上残存筋弛緩の発生を減らせた。ネオ スチグミンによる拮抗は, 高齢, ASA 分類が高い例, セボフルラン麻酔, ロクロニウムの投与量が多い例, ロクロニウムの最終投与から拮抗までの時間が短い 例で不十分になりやすかった。 スガマデクス投与で も筋弛緩が残存することもあるのでモニタリングし て確認する必要がある。

\section{参考文献}

1) Murphy GS, Szokol JW, Marymont JH, et al. : Residual neuromuscular blockade and critical respiratory events in the postanesthesia care unit. Anesth Analg $107:$ 130-137, 2008

2) Eriksson LI, Sato M, Severinghaus JW : Effect of a vecuronium-induced partial neuromuscular block on hypoxic ventilatory response. Anesthesiology 78 : 693699, 1993

3) Kopman AF, Yee PS, Neuman GG : Relationship of the train-of-four fade ratio to clinical signs and symptoms of residual paralysis in awake volunteers. Anesthesiology $86:$ 765-771, 1997

4) Eikermann M, Vogt FM, Herbstreit F, et al. : The predisposition to inspiratory upper airway collapse during partial neuromuscular blockade. Am J Respir Crit Care Med $175:$ 9-15, 2007

5) Gätke MR, Viby-Mogensen J, Rosenstock C, et al. : Postoperative muscle paralysis after rocuronium : less residual block when acceleromyography is used. Acta Anaesthesiol Scand 46 : 207-213, 2002

6) Maybauer DM, Geldner G, Blobner M, et al. : Incidence and duration of residual paralysis at the end of surgery after multiple administrations of cisatracurium and rocuronium. Anaesthesia $62: 12-17,2007$

7) Baillard C, Clec'h C, Catineau J, et al. : Postoperative residual neuromuscular block : a survey of management. Br J Anaesth 95 : 622-626, 2005

8) Cammu G, De Witte J, De Veylder J, et al. : Postoperative residual paralysis in outpatients versus inpatients. Anesth Analg 102 : 426-429, 2006

9) Murphy GS, Szokol JW, Marymont JH, et al. : Residual paralysis at the time of tracheal extubation. Anesth Analg $100:$ 1840-1845, 2005

10) Vanacker BF, Vermeyen KM, Struys MM, et al. : Reversal of rocuronium-induced neuromuscular block 
with the novel drug sugammadex is equally effective under maintenance anesthesia with propofol or sevoflurane. Anesth Analg 104 : 563-568, 2007

11) Eleveld DJ, Kuizenga K, Proost JH, et al. : A temporary decrease in twitch response during reversal of rocuronium-induced muscle relaxation with a small dose of sugammadex. Anesth Analg 104 : 582-584, 2007

12) Suzuki T, Kitajima O, Ueda K, et al. : Reversibility of rocuronium-induced profound neuromuscular block with sugammadex in younger and older patients. $\mathrm{Br} \mathrm{J}$ Anaesth $106: 823-826,2011$

13) Debaene B, Plaud B, Dilly MP, et al. : Residual paralysis in the PACU after a single intubating dose of nondepolarizing muscle relaxant with an intermediate duration of action. Anesthesiology 98 : 1042-1048, 2003

14) Fuchs-Buder $T$, Tassonyi $E$ : Magnesium sulphate enhances residual neuromuscular block induced by vecuronium. Br J Anaesth $76: 565-566,1996$

\title{
Reversal of Neuromuscular Block and Residual Paralysis in Japan
}

\author{
Itsuo NAKATSUKA \\ Department of Anesthesiology, School of Medicine, Keio University
}

We assessed the incidence of residual neuromuscular block (train of four ratio $<0.9$ ) after reversal with neostigmine or sugammadex following administration of rocuronium without using neuromuscular monitor. After reversal of neuromuscular block, adequate recovery was judged subjectively by the attending anesthesiologist and the trachea was extubated afterward. The incidence of residual paralysis just after extubation was $23.9 \%$ with neostigmine but was significantly reduced to $4.3 \%$ with sugammadex. Factors of residual paralysis in the neostigmine group were older age, higher dose of rocuronium supplementation, lower dose of neostigmine, and shorter time from the last rocuronium administration to neostigmine administration, but no clear factors of residual paralysis in the sugammadex group were found.

Key Words : Rocuronium, Neostigmine, Sugammadex, Residual neuromuscular block

The Journal of Japan Society for Clinical Anesthesia Vol.33 No.2, 2013 